\title{
Poder e gênero no século 21
}

\author{
O bra analisa mudanças etnográficas globais na família ao lon- \\ go do século passado e ao redor do mundo. Em particular, \\ acompanha criticamente as revoluções pelas quais passaram 0 \\ patriarcado, o casamento e a fecundidade. Em perspectiva, \\ analisa o novo papel social das mulheres.
}

\section{por Márcia Canvalho deAzevedo}

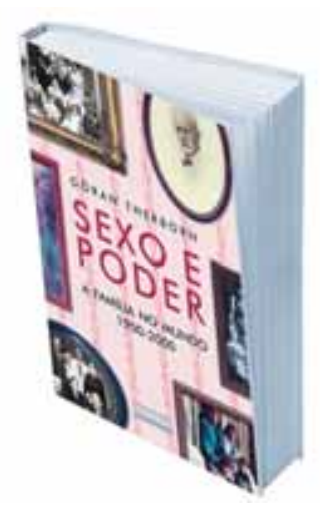

Sexo e Poder: A Família no Mundo 1900-2000 GöranTherbom Editora Contexto, 2006

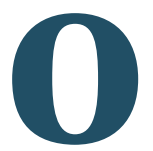
livro do destacado sociólogo sueco Göran Therborn éo resultado de um impressionante trabalho de pesquisa comparativa realizado ao longo de 8 anos. 0 estudo fez uso de uma bibliografia extremamente ampla e foi baseado em fontes globais, 0 que permitiu uma compilação única de dados históricos. Therborn apresenta uma enorme quantidade de informações e faz um mapeamento detalhado e original da evolução da família e do patriarcado como regulador das relações sociais ao longo do século 20.

As mudanças na estrutura familiar são discutidas por meio de três temas principais. 0 patriarcado e os direitos e deveres relativos de pais e filhos, homens emulheres éo primeiro tema. Nessa parte são analisados os poderes familiares masculinos. 0 foco aqui são as relações entre pais e filhos adultos e entre maridos e esposas. 0 segundo tema é o papel do casamento e do não casamento na regulação do comportamento sexual e nas ligações sexuais em particular. 0 terceiro tópico aborda o passado, o presente e as perspectivas futuras da fecundidade e do controle de natalidade.
Na primeira parte do livro o autor apresenta um panorama do patriarcado do início do século 20 até o século 21. "Sexo e Poder" afirma que o mundo até o início do século passado era basicamente patriarcal. Tinha como base de sustentação o poder dos homens mais velhos sobre os jovens e a superioridade institucionalizada dos homens sobre as mulheres. Porém uma importante mudança começou no início do século passado, nos países escandinavos, com a conquista de direitos das mulheres e das crianças.

Os dados compilados mostram que o patriarcado foi um dos grandes perdedores do século 20. Apesar disso, ele ainda está longe de extinção. Apenas $30 \%$ da humanidade vive em sociedades pós-patriarcais. De qualquer forma, éindiscutível que o poder patriarcal vem perdendo espaço de forma contínua, na medida em que os direitos legais das mulheres e das crianças foram sendo ampliados em todos os países.

$\mathrm{Na}$ segunda parte do livro $\mathrm{O}$ autor discute as mudanças na estrutura do casamento. Ao contrário do que o senso comum poderia supor, atualmente, 0 
percentual de mulheres que se casam antes do final de sua vida fértil é praticamente 0 mesmo que há 100 anos. No entanto, o contexto social e sexual dos casamentos nos dias de hoje é muito diferente. Como aponta Therborn: "O casamento não está desaparecendo. Está mudando". 0 modelo de casamento universal continua predominante em diversas regiões do mundo e mantém a posição de instituição dominante da ordem sociossexual global. Apesar disso, cerca de $40 \%$ da população mundial possui atualmente um padrão pluralista de relações sexuais.

A terceira parte do livro é dedicada ao tema fecundidade e suas mudanças no século passado. Os dados indicam um declínio em duas diferentes ondas internacionais. A primeira, na França enos EUA no começo do século 19; a segunda, global, no último terço do século 20. A pontar as razões das ondas de declínio da natalidadenão é uma tarefa simples. Existem diversas teorias explicativas para 0 fenômeno e 0 autor propõe um quadro de interpretação com dois el ementos principais: um senso de domínio pessoal eum senso dos benefícios de se ter menos fiIhos. A fecundidade global caiu de um pico de 4,9 filhos por mulher nos anos de 1960 para 2,7 no início do século 21.

0 livro também apresenta al guns dados sobre o Brasil, indicando uma mudança nas relações entre gênero e apontando para o fato de que o grupo feminino vem ganhando mais poder dentro da sociedade brasileira. Deve-se ressaltar, no entanto, que nos últimos anos temos observado um renascimento religioso que promove o domínio da família pelo homem. Para Therborn, atualmente, é difícil avaliar o real impacto que esses movi- mentos terão na posição da mulher nas sociedades em que esse fenômeno vem ocorrendo.

0 livro éuma obra fundamental para o estudo da estrutura familiar e suas relações de poder. 0 autor fez um trabaIho original e ousado ao sintetizar de forma objetiva as mudanças mundiais da família no decorrer do século passado. Pelo cenário analisado, percebemos que a família se transformou, mas não de uma forma regular nem única, descartando qualquer abordagem evolucionista do fenômeno. As mudanças no patriarcado, no casamento e na fecundidade promoveram uma revolução do comportamento social e pessoal quefomentou a emancipação das mulheres de sua antiga posição de inferioridade social e institucional em relação aos homens.

\section{Márcia Carvalho deAzevedo}

Profa. do Departamento de Administração da PUC Campinas

Doutoranda em Administração de Empresas pela FGV-EAESP

E-mail: marciac@bestway.com.br

\section{A família éuma instituição fundamental em nossa sociedade. U ma análise sobre as mudanças em suas estruturas no século 20 auxilia 0 entendimento das transformações ocorridas nas relações entre os gêneros e suas conseqüências no século 21.}

